\title{
The American Research University System as America's de facto Technology Policy
}

\author{
Michael M. Crow and Christopher Tucker
}

June 1, 1999

\section{Introduction}

The American research university system, as it has evolved through policies and actions in the last 50 to 60 years constitutes a de facto technology policy. Some have focused on the fact that America has had multiple technology policies, not to mention multiple science policies, with different Agencies making different decisions about the fields of science and engineering they wish to support. But, few have focused their attention on the emergent effect of these science and technology policies - namely, that they have fueled an American research university system that has underpinned technological development within and across a wide variety of emerging and mature industries. Universities have been important vehicles through which all federal agencies have realized their missions through R\&D support. But beyond supporting specific agency missions, these technology policies have had the cumulative effect of building a technology policy profile for the United States that has gone largely unrecognized, or at least unappreciated.

Ever since Vannevar Bush's Science the Endless Frontier, American policymakers and scholars of science and technology policy have thought of American research universities in terms of their contribution to basic research. While there have been interludes such as during war or space program buildups where 'engineering' or 'technology' have received more attention, the direct contribution of universities to technical advance in industry has largely been overlooked. 
This paper investigates the mindset that has led the American research university system to be overlooked as a foundation of any discussion of American technology policy. This paper also studies the historical factors that have led to the development of this system and its importance as a key policy phenomenon supporting technical advance in industry.

\section{A Different Perspective on Technology Policy}

In Vannevar Bush's report, Science the Endless Frontier, his insistence that basic research is both necessary and sufficient for technical progress and his characterization of universities as performers of basic research were complementary arguments in the service of his larger political goal - to secure political autonomy for a scientific community that would receive the bulk of its funding from the federal government.

While Bush was successful in designing a system that has led to an unprecedented federal financial commitment for university-based basic research, structured to provide significant grants of autonomy, this commitment was at the expense of a true accounting of the innovation process. Bush chose to de-emphasize the university as a performer of anything other than basic research, as well as the spectrum of research that universities contributed to, despite his knowledge of the subject (Nelson, 1997). In the face of conservative elements concerned with the "crowding out" effect of public investment in applied research, Bush found it politically expedient to sustain this conceit.

Prior to the Bush report, American research universities fostered the emergence and growth of university-centered scientific and technical information networks that served as the spawning ground for new technological and new commercial enterprises. 
Before 1945, universities had engaged in a spectrum of research, from fundamental to applied, at many points in the evolution of technologies/industries ranging fom hybrid corn and electronics to electrochemicals and telecommunications. After the Bush report, and the subsequent expansion of funding for basic research, both federal and state policies toward universities allowed these institutions to contribute to technical advance in industry through more than just basic research. For sure, the emphasis was shifted considerably by Bush's line of argument toward basic research. But, the operational level concerns of policymakers in sectors like health, defense, agriculture, transportation and the like, have ensured that some level of resources would be dedicated to universitybased research that is strongly linked to notions of use.

The simplifications Bush presented provided a rhetorical tool that helped in the fight for federal support for university-based basic research. Roughly the same rhetorical strategy continues to be used by many universities and their advocates today. Universities and their advocates consciously or unconsciously choose to continue the mischaracterization of the nature of university research and its role in supporting technological advance in industry. They continue Vannevar Bush's campaign for enhanced federal financial contribution of university-based basic research, with broad grants of autonomy - contributing, along the way, to the belief that universities contribute to industry mainly through the magnitude of its basic research portfolio.

In truth, American research universities have served as complex institutional underpinnings of technological advance in industry (Florida, 1999). They have served in this role by performing a spectrum of federally, state, and industry sponsored research, from basic to applied, despite Bush's emphasis on universities as performers of basic 
research. But more importantly, American research universities have served this role by training students in the latest technologies and by professors, science and engineering departments, and research centers forging relationships with industry. In these relationships, universities have served as institutional resources that have been cultivated and drawn upon by industry. A surprising institutional capacity developed under these policies, yet we have largely ignored its impact as a kind of de facto technology policy phenomenon because of its radical differences with the European and Asian technology policies that Americans typically consider benchmarks.

\section{The Mischaracterization of Universities in the American Technology Policy Debate}

The current attention paid to "technology policy" in America has its roots in the industrial policy debate of the 1970s and 80s.

In the face of sturdy competition from Japan and the newly industrializing countries (NICs) during the 1970s and 80s, many American and European commentators came to extol the virtues of coordinated technology or industrial policies (Reich, 1982; etc.). In response to the perceived threat, Europeans began launching some large-scale coordinated technology policies. Americans began by branding every policy initiative, both new and old, with provisions that could enhance America's “competitiveness". For instance, in the "competitiveness" spirit, various efforts were made to incent the transfer of new technologies from research institutions (be they national labs, or universities) to industry, such as the Bayh-Dole Act of 1980. Then Americans proceeded to spend much of the 1970s and 1980s arguing over the meaning and appropriateness of 'industrial policy'. 
To begin the 1980s, American labor and basic manufacturing interests argued strenuously for a concerted national policy initiative to restore American economic stability (UAW, 1983; AFL-CIO, 1983; AFL-CIO, 1984). Viewing the Japanese and Korean experiences as examples of economic planning that should be envied and even emulated, these interests worked successfully to have elements of a coordinated industrial policy integrated into the platform of the American Democratic party (U.S. Congress, 1983; Reich, 1982). However, due to political misfortunes faced by the Democrats in the 1984 presidential election, the notion of a coordinated industrial policy became splintered, only to survive in American policy circles through a scattering of technology policies and trade policies.

For much of the 1980s, discussions of technology policy largely revolved around the role of government in supporting pre-competitive (or generic) applied research as well as the propriety of government supporting large scale coordinated technology development programs such as the breeder reactor and high-speed rail. The only technology policy initiative that explicitly linked universities to technical change in industry was the National Science Foundation's Engineering Research Centers (ERC) Program, which made its first awards in 1985. Building upon the Industry-UniversityCooperative Research Centers Program that began in 1979, the ERC program was a small effort that has had mixed results.

By and large, universities were left out of any systematic consideration in terms of technology policy during the 1980s. There was no recognition that long before this particular industrial policy debate began, American research universities had a long 
history of shaping the rate, direction and character of technological change in industry, influenced by an array of uncoordinated (defense, agriculture, health, manufacturing, trade, education, banking, tax, and so forth) policies.

When science was mentioned in the debates of the 1980s, it was often in the context of university-based basic research. The Bush legacy continued to guide the thinking of most policymakers. Little attention was paid to the historic role of universities as active participants in industrial development. More broadly, the rich mix of policies and institutions that have supported American technological leadership (and occasional fall from leadership) in the post WWII era have largely been unappreciated (save for, Nelson and Wright, 1992; Nelson, 2000). The complex relationship of American research universities to recent American technological performance has certainly been given short shrift, which seems particularly odd given the composition of industries and technologies that will likely be fundamental to future industrial development, such as biotechnologies, digital technologies, and advanced materials.

\section{The Emergence of the Research University}

The history of the "research university" is long and rich. It is a story of a complex interplay between evolving modes of knowledge production and institutional development. An examination of the roots of the research university provides us with an impression of how recent a development the contemporary American research university system actually is, as well as its importance in the American technological experience as a de facto technology policy. 
The norms of open science emerged in the scientific societies and academies of the $17^{\text {th }}$ century, as a response to the narrow and antiquated university curricula that that clearly opposed the ideologies of the Enlightenment. These norms of open science are commonly characterized as unfettered discretion (institutional autonomy), a winner-takeall competitiveness among individual investigators, and an entrepreneurialism in assembling necessary resources. Researchers' concern for priority (that is, their interest in being first to discover new knowledge) is thought to be one of the primary forces behind the common scientific practice of placing advances into the public domain, to be disseminated as widely as possible (David and Dasgupta, 1994).

Over a hundred such societies and academies emerged of various sizes and importance, leading to an international community of scientists embodying the norms of open science (Guena, 1996). After more than two centuries of atrophy, the university as an institution began a revitalization as it faced a more desirable political and religious environment, and as it absorbed the norms of open science developed by the academies. It is out of this revitalization that the new models of teaching and research developed in Germany, England, and France (Ziman, 1984).

Though typically invoked as the norms of open science, these norms were adhered to during a period prior to the existence of the scientific disciplines we think of today. Indeed, this early mix of the discovery of natural phenomena and fundamental technological advance made few of the distinctions such as 'basic' and 'applied' that preoccupy contemporary analysts. The principle of priority was widely held by inventors and discoverers alike as they fought for unfettered discretion (institutional autonomy) to 
work relentlessly to assemble to necessary resources in order to win in this winner-takeall competition.

Under the broad logic of open science, a number of different strands of research universities took hold before 1850; each peculiar to its own national history. England had Oxford and Cambridge, but it also had the Royal Institution of London that served as a center for both fundamental and applied scientific laboratory work in the Baconian tradition. France, under Napoleon, developed Ecoles that were designed to support the development of a strong engineering class and bureaucratic class and to secure strength and capacity for empire building. The German research universities grew up as institutions encompassing the literature and philosophy of the Romantic period and strong theoretical and empirical work in the sciences. And, by this time, other European science centers had emerged.

While the elite American colleges were built originally to educate gentlemen in the ways of theology, languages and the classics, they too were soon subjected to the powerful influence of this international scientific community (Rudolph, 1962; Veysey, 1965).

America had little in the way of 'research' going on during this period. West Point (United States Military Academy) was a center of engineering excellence, but science had no place. Rensselaer Polytechnic Institute was established in the 1820 s modeled on the French Ecoles, but it did not embrace the sciences fully until it reorganized just before 1850. By the 1850s-60s, some 'scientific schools' were established within more traditional American colleges like Harvard, Yale and Columbia (Yale's was organized around applied chemistry; Harvard's around zoology and botany; 
Columbia's around the fields related to mining). The scientific schools were hardly welcomed into these institutions, but they were widely emulated by other colleges over the $1850 \mathrm{~s}$ and $60 \mathrm{~s}$, institutionalizing a home for science and engineering in American college curricula. These schools sowed the seeds for their later transformation into research universities (Veysey, 1965; Geiger, 1986).

By the mid-1870s, Land Grant universities had been established in many states under the Morrill Act of 1863 in support of agriculture and mechanical arts. The establishment of these institutions was the primary factor driving in the geographic dispersion of scientific and engineering skills in America during this period (Ross, 1942). At the same time, aspects of the German research university transferred to American with the establishment of Johns Hopkins in 1876. Germany's research universities had risen to clear prominence in chemistry, physics and agricultural sciences. Johns Hopkins, and the American institutions that modeled themselves after it, enabled America to host similar success in science and engineering over the next several decades.

By just after the turn of the century, American institutions of higher education had evolved into a structure recognizable by today's categories. At that time there were 15 universities that resembled what we now call research universities. Johns Hopkins, Stanford, and Chicago had been founded as research universities, adapted from the German model. Columbia, Harvard, Penn, Princeton, and Yale had successfully evolved from being traditional elite colleges specializing in languages, religion and the classics into developing centers of scientific and engineering research. MIT and Cornell evolved from technical school and ivy-league foundations, respectively, as land-grant institutions. 
Illinois, Michigan, Minnesota, Wisconsin, and California developed state universities that had scientific and engineering research at their core.

The norms of open science had found an institutional vehicle in the American research university. These institutions provided a permanent home for American scientists and engineers that had found little in the way of institutional support during the earlier parts of the $19^{\text {th }}$ century. They now had an institutional foundation that was designed to enable the unfettered discretion (institutional autonomy) that researchers desperately sought to assemble the resources necessary to be effective.

The entrepreneurialism that was encouraged under the norms of open science led colleges and universities, during this period, to serve as the locus of the interplay between scientific and disciplinary differentiation and the development of applied fields of knowledge. The evolution of the American research university occurred hand in hand with the development of the engineering and applied science fields such as electrical engineering, chemical engineering, mechanical engineering, and aeronautical engineering. These universities were the incubators for scientific and technical information networks in which communities of innovators, and increasingly, firms were embedded (Rosenberg and Nelson, 1994). This pattern of disciplinary differentiation continued with, for example, electrical engineering spawning radio engineering and ultimately, electronics. This pattern is prominent over the six decades spanning the turn of the $20^{\text {th }}$ century (Tucker, 1999). 


\section{The Bush Report and Disciplinary Diversification}

Vannevar Bush, in his famous report Science the Endless Frontier, overwhelmingly failed to characterize the interplay of universities and technological change in this way, despite his own understanding of these matters (Zachary, 1998). Bush argued that universities were, and should be performers of basic research. In reality, Bush was ensuring support for basic research at universities within an uncoordinated policy regime that had supported (and continues to support) a variety of applied science and engineering research within and beyond universities. In turn, Bush contributed to the massive growth of a wide range of research capabilities (basic, applied, fundamental technology development, etc.) within American research universities.

Under the vastly increased funding brought to universities, these relatively autonomous institutions enabled disciplinary developments that took advantage of the free interplay between curiosity-driven basic research, mission- (or use-) oriented basic research, fundamental technology development, and not-so-fundamental technology development. While there have been clear problems with disciplinary balkanization within universities, this problem is not uniform within or across institutions. And despite such problems, universities have provided a relatively open environment for this type of free ranging experimentation.

Rather than embracing the diversity of research that co-mingles within universities, the linear model focuses our attention on the science departments of American research universities; biology, chemistry, physics and their sub-disciplines. But, as discussed above, this is to the neglect of the applied sciences and engineering 
disciplines such as chemical engineering, electrical engineering, aeronautical engineering, mechanical engineering, applied physics, and so forth (Rosenberg and Nelson, 1994). The linear model forces us to miss the richness of university commitments to applied endeavors that have proven, historically, to have significant industrial applicability.

The growth of the post-WWII research university was particularly dependent upon disciplinary diversification and the complex interplay of these different modes of research. Some examples may help.

The strengthening of America's historic commitment to supporting agriculture through education and research witnessed rapid disciplinary diversification in land-grant research universities in the post-WWII era. These agriculture-specific disciplines are no less fundamental than traditional university science disciplines. But fields such as entomology, soil sciences, plant molecular biology, microbial ecology, and nutrition sciences are deeply applied and critical to the accomplishment of national, industrial and regional goals in agricultural development. Moreover, they are intimately related to areas of university research that are typically considered more in line with the model of a 'research university'. Where would entomology be without biology? And where would soil sciences be without chemistry? In this case, universities have housed a wide range of research.

The U.S. federal commitment to health research throughout this century has driven incredible disciplinary diversification. We see this phenomenon reflected in the growth of U.S. academic medical centers. These institutions house basic biosciences, clinical departments and medicine departments that co-mingle freely and that are 
intimately related to the standard university basic sciences and engineering disciplines. They are no less fundamental, but are often highly applied to particular problems. But, where do they lie on the linear model? (Stokes, 1997).

Computer science is yet another post-WWII example of the disciplinary innovation at the core of this pattern of growth and diversification among American research universities. Information technology, more broadly, has been driven over the past fifty years by a federal commitment to the support of university based research into every aspect of computer languages, signal processing, networking, data storage, and applications. These are fundamental technology development efforts. Yet, they also owe much to the bodies of knowledge developed by the traditional university disciplines. Our ability to encode information in electronic signals, and then to process and compute these signals is a skill that has drawn upon scientific and engineering expertise in many fields, from physical chemistry and applied mathematics to applied physics. This work is highly applied, yet often quite fundamental.

This disciplinary diversification was part in parcel of the rapid growth of American research universities in the post-WWII era - only to be enhanced after the launch of Sputnik. Throughout this expansion, these universities have served as enabling environments for researchers to freely span fundamental and applied work, if that is what they so pleased.

\section{Growth and Dispersion of American Research Universities in the Post-WWII Era}

The growth of federal funding for university-based research and the related disciplinary diversification presented niche opportunities for new entrants. No single 
institution could possibly encompass all of the existing fields of research. Specialization among universities necessarily followed, with some focusing on medical research, others on engineering, and still others on the traditional scientific disciplines.

Institutional autonomy, which was the means to support the largely unfettered discretion sought by researchers, was quite important in the growth and dispersion of the American research university community. Often playing on their comparative advantages, universities exercised institutional discretion in pursuing disciplinary and resource niches in order to achieve some stature as institutions dedicated to research. This was the organization-wide manifestation of the same entrepreneurialism borne of priority in discovery.

Through this pattern of disciplinary diversification and resource growth, the major public and private research universities that were prominent earlier in the $20^{\text {th }}$ century continued as research leaders. However, the proliferation of new research questions offered opportunities for advancement for both public and private universities that had less prominent reputations for research earlier in the century.

In effect, 'the rising tide raised all boats,' though it raised some faster than others (Graham and Diamond, 1997). Public universities like UC-San Diego and the University of Washington have grown quite large, world-class research portfolios in an incredibly short period of time. Under significant state-level support, these universities have come to compete successfully for federal research funds. Private universities like Duke and Rensselaer Polytechnic Institute have grown into significant research institutions also, with private development efforts evolving successful federally-sponsored research 
portfolios. While some of these institutions have grown faster than others, in terms of their research portfolios, they have all followed niche strategies.

As such, one can discern not one American research university model, but several that shared the norms, and resultant behavioral attributes, of open science. These attributes included institutional autonomy (in relation to federal control); a competitiveness among individual investigators, departments, and universities; and the entrepreneurialism necessary to assemble the requisite resources to succeed in this highly competitive environment.

\section{The Critical Role of American Research Universities in Shaping National Technological Performance}

Although American research universities have not been considered as explicit parts of the American technology policy debate, the norms of open science as augmented by federal patronage have done much to support American technological development. There are many prominent examples of large postwar developments in science, the applied sciences and engineering that saw major federal support that helped transform the landscape of American research universities. And many of these, including computer science, the biosciences, materials sciences, various aspects of physics (applied, quantum, nuclear, condensed matter), and plant hybridization have been at the center of important industrial developments.

Over the past two centuries it has become abundantly clear that the R\&D division of labor among firms and universities can vary widely by discipline, technology and industry (Tucker and Nelson, forthcoming). However, some underlying patterns tend to 
hold true. While universities develop many different types of knowledge poducts embodied in ideas, innovations, artifacts, articles and individuals, it is firms that are the organizations that have the comparative advantage in "making airplanes," "designing microprocessors," and otherwise producing goods and providing services (Nelson, 1990). With their senses trained on particular markets and their competencies honed to particular niches, firms are the locus of much learning related to the advance of particular goods and services. But, their continued vitality often depends on the rejuvenating forces offered by universities in the variety of knowledge they generate.

A range of university-industry interactions sustains long run technological change. Some are direct such as the diffusion of trained scientific and technical personnel embodying pertinent knowledge and the development of university spin-off companies. Others are indirect such as the development of instrumentation and methodologies that are absorbed into industrial practice (Rosenberg, 1994). Still others are difficult to capture empirically such as the access firms might have to university based knowledge networks for both infrastructural knowledge or an interdisciplinary mix of university researchers capable of solving complex problems. These interactions differ by fields of science, areas of technology, and industry. Yet, universities play critical roles in supporting innovation through basic science and a wide array of other modes of research.

\section{The Bayh-Dole Conception of the American Research University}

To some, recent changes in federal policies towards university patenting -specifically the Bayh-Dole Act of 1980 -- may appear to challenge the thesis that 
universities have not been explicitly considered as technology policy instruments. The Bayh-Dole Act was passed in response to the argument that the fruits of federally-funded university-based research -- traditionally placed in the public domain -- had often times not been effectively transferred into American industry. Bayh-Dole allowed universities to patent inventions resulting from federally-sponsored research, and to license these patents to industry. It aimed at creating financial incentives for universities to market these technologies, and, through allowing for limited monopoly power, for firms to commercialize these technologies (see Mowery et al. 1999 for an assessment of BayhDole.) Indeed, it has prompted university involvement in all sorts of licensing arrangements and entrepreneurial start-ups (Siegel, Waldman and Link, 1999).

However, it is important to note that the argument leading to the passage of BayhDole was sung to the tune of the linear model: universities were performers of basic research, largely uninterested in practical ends. While in the legislation there was the token mentioning of support for economic development, the intended purpose of allowing universities to retain title to these inventions and to license them to firms was to facilitate technology transfer, not to target university research towards technological or economic needs (Eisenberg, 1996).

For example, in his testimony in favor of the Bayh-Dole act Willard Marcy, Vice President of the Research Corporation, a non-profit organization that patented and licensed university inventions since the 1930s, notes: "[University scientists] are often the last to recognize what inventions are useful to the general public. They are science oriented, and frequently, not knowledgable in the marketplace. Their useful inventions 
are mostly fall out from their scientific investigations" (U.S. Senate, 1979). Such a statement is hardly an affront to the linear model.

It is interesting to note, however, that there is some speculation that the BayhDole act may have unintentionally shifted university research from "basic" to "applied". The notion here is that a result of Bayh-Dole and related changes in norms about academic patenting, university researchers have become more commercially oriented, at the expense of fundamental research. However, there is little empirical evidence that either substantiates or refutes this hypothesis (Nelson, 2001).

Indeed, it is difficult to test this hypothesis precisely because the lion's share of university patenting lies in fields like biotechnology, where policymakers' traditional distinctions between "basic" and "applied" break down (Mowery et al. 1999). However, in light of prior arguments, it would seem that the answer to this question is less important than the perspective from which it is asked. It assumes that university research has, historically, been basic in nature and that research clearly linked to industrial applications (or inspired by concerns over use) is an indication of contamination by nonscholarly concerns.

The research undertaken in American research universities has run the gamut of basic to applied. And the resources that have been applied to these institutions have led to a variety of benefits for technical advance in industry. The Bayh-Dole Act was certainly an interesting institutional innovation that has both provided many universities with additional resources and licensed unprecedented volumes of innovations to industry. But, the Act certainly cannot be thought of as a recognition of the American research university system's role in American technology policy. 


\section{Diagnosis of the Coordinated Technology Policy Desire}

We have presented an explanation of why American research universities have been mischaracterized in debates over American technology policy. And, we have discussed the ways in which the American research university system has fundamentally supported technological advance in industry. But this provides only part of the explanation for why the large and diverse population of American research universities is so often passed by in discussions of American technology policy.

Those of the Bushian persuasion overwhelmingly conceive of the university's role in the economy as limited to the performance of basic research. The success of their argument in policy circles has left little room for understanding the variety of ways in which university research supports industrial development. Heavily swayed by this perspective, discussions relating to policies and programs that might enhance American industrial performances, often on an industry-by-industry basis, have largely overlooked universities as explicit components.

Instead, American policy makers have simply assumed universities as pre-existing conditions for technology policy making. After making this assumption, these policy makers have conceived of "technology policy" as coordinated programs that are targeted toward augmenting some field of technology or overcoming some class of technological problems.

Despite the reality that American research universities were involved in

industrially relevant research, they have never been thought through in terms of a coordinated technology policy. In part, this is due to the significant discretion that 
American research universities have had vis-à-vis the national government, relative to universities in other countries. And in part, this is due to the Bush legacy.

Whether or not American research universities would contribute better to American industrial development if they were thought of as institutional resources to be coordinated within a national technology policy is a counterfactual that is difficult to evaluate. But it is interesting that this question has not ever been dealt with. In the U.S., our efforts at coordinated technology policy tend to have little to do with the massive institutional infrastructure of the American research universities, even though the development of these institutions has been strongly influenced by a variety of public policies. It seems clear that the failure to recognize American research universities as institutional resources that are critical to American technological performance has profoundly limited the success of America's coordinated technology policy efforts.

\section{Reflections}

The policy implications of this misguided perspective have been profound. The university community itself has continually thought of itself in terms of Vannevar Bush's vision, and has actively undermined efforts to support applied research initiatives that they believe might siphon resources from basic research. Meanwhile, they have been opportunistic in their funding quests, leading to a rich and variegated mix of applied research at American research universities - despite the system, not because of the system.

Also, industry has continued to bemoan the university community's lack of interest in engaging in industrial useful $\mathrm{R} \& \mathrm{D}$, despite this rich mix of industrially 
important research. This seeming conundrum is brought about by the unwillingness of a majority of American research universities to explicitly organize themselves to undertake industrially relevant research. This conundrum is also brought about by policymakers that on the one hand target non-trivial proportions of federal support for university research to industrially relevant research, but yet adhere strictly to the rhetoric first set forth by Vannevar Bush.

The opportunity cost of not recognizing that the American research university community as a key element of America's de facto technology policy has been huge. It has become more obvious as industry groups, over the last 15 years, have developed technology roadmapping activities that explicitly lay out as industry's technology goals and the variety of scientific and technical roadblocks that must be overcome by the relevant technical communities before an commercial value can be realized. In this context, not recognizing the importance of the research universities in overcoming these roadblocks and explicitly mobilizing universities to support industry in this manner seems absurd.

Overcoming this conceptual limitation would make it much easier for all involved to realize the types of patterns of university-industry interaction that we have witnessed historically. Perhaps alleviated much unneeded anxiety. 


\section{Bibliography}

AFL-CIO. 1983. Rebuilding America: A National Industrial Policy. Washington, D.C.: Industrial Union Department.

AFL-CIO. 1984. Deindustrialization and the Two Tier Society: A Challenge for an Industrial Policy. Washington, D.C.: Industrial Union Department.

Brooks, H. 1996. "The Evolution of U.S. Science Policy” in Technology, R\&D, and the Economy, Bruce L.R. Smith and Claude E. Barfield, eds. Washington: The Brookings Institution and American Enterprise Institute.

Bush, Vannevar. 1945. Science The Endless Frontier. Washington, D.C.: Office of Scientific Research and Development.

David, P. A. and P. Dasgupta. 1994. "Toward a New Economics of Science," Research Policy.

David, P.A. 1994. "Reputation and Agency in the Historical Emergence of the Institutions of 'Open Science'," MERIT Research Memorandum 2/94-006.

Dupree, A. H. 1957. Science in the Federal Government: A History of Policies and Activities to 1940. The Belknap Press of Harvard University Press: Cambridge. 
Eisenberg, Rebecca. 1996. Public research and private development: patents and technology transfer in government sponsored research. Virginia Law Review 82: 1663-1727.

Geiger, Roger. 1986. To Advance Knowledge. New York: Oxford University Press.

Geiger, Roger. 1993. Research and Relevant Knowledge. New York: Oxford University Press.

Graham, Hugh Davis and Nancy Diamond. 1997. The Rise of American Research Universities: Elites and Challengers in the Post-War Era. Baltimore: Johns Hopkins University Press.

Guena, Aldo .1998. "Resource Allocation and Knowledge Production: Studies in the Economics of University Research," Maastricht Dissertation 98-41.

Guena, Aldo. 1996. "European Universities: An Interpretative History," MERIT Research Memorandum 2/96-012.

Mowery, David C. and Richard R. Nelson, 1996. "The U.S. Corporation and Technical Progress" in Kaysen, Carl (ed.). 1996. The American Corporation Today. New York: Oxford University Press. 
Mowery, David, Richard R. Nelson, Bhaven Sampat, Arvids Ziedonis. 1998. "The Effects of the Bayh-Dole Act on U.S. University Research and Technology Transfer: An Analysis of Data from Columbia University, the University of California, and Stanford University." Presented at conference on The U.S. and Japanese Research Systems (Kennedy School of Government, Harvard University). September 10-12, 1998.

Nelson, Richard R. 2001. "Observations on the Post-Bayh-Dole Rise of Patenting at American Universities," forthcoming, Journal of Technology Transfer, special issue on “Organizational Issues in University-Industry Technology Transfer” (Vol. 26, Nos. 1-2)

Nelson, Richard R. (ed.) 2000. The Sources of Industrial Leadership. Cambridge University Press.

Nelson, Richard R. 1990. "Capitalism as an Engine of Progress," Research Policy. 193214.

Nelson, Richard R. 1997. "Why the Bush Report Has Hindered an Effective Civilian Technology Policy," in Barfield, Claude (ed.). 1997. Science for the Twenty-first Century: the Bush Report Revisited. Washington, D.C.: AEI Press.

Nelson, Richard R. and Gavin Wright. 1992. "The Rise and Fall of American Technological Leadership: The Postwar Era in Historical Perspective," Journal of 
Economic Literature, December, pp: 1931-1964.

Reich, Robert B. 1982. "Why the U.S. Needs an Industrial Policy," Harvard Business Review 60 (Jan/Feb): 74-81.

Rosenberg, Nathan and Richard Nelson. (1994). "American Universities and Technical Advance in Industry". Research Policy, 23(3).

Rosenberg, Nathan. 1994. "Scientific Instrumentation and University Research." Exploring the Black Box: Technology, Economics and History. Cambridge University Press. pp. 250-263.

Rosenbloom, Richard S. and William J. Spencer. 1996. Engines of Innovation: U.S. Industrial Research at the End of an Era. Boston, MA: Harvard Business School Press.

Ross, E. D. 1942. Democracy's College: The Land-Grant Movement in the Formative Stage. Ames.

Rudolph, Frederick. 1962. The American College and University: A History. New York: Knopf Press.

Siegel, Donald, David Waldman, and Albert N. Link. 1999. "Assessing the Impact of Organizational Practices on the Productivity of University Technology Transfer Offices: 
An Exploratory Study,” NBER Working Paper \#7256, July.

Smith, B. L. R. 1990. American Science Policy Since World War II. Washington, D.C. : Brookings Institution.

Stokes, Donald E. 1997. Pasteur's Quadrant: Basic Science and Technological Innovation. Washington, D.C.: Brookings Institution Press.

Tucker, Christopher and Richard R. Nelson. Forthcoming. "The Hybrid Seed Industry and the Public/Private R\&D Division of Labor". Working Paper: Columbia University.

Tucker, Christopher. 1999. "The Role of Government in Supporting Technological Advance," Dissertation: Columbia University.

U.S. Congress. 1983. Forging An Industrial Competitiveness Strategy. House Committee on Banking, Finance, and Urban Affairs. Subcommittee on Economic Stabilization.

U.S. Senate. 1979. Hearings before the Committee on the Judiciary, U.S. Senate, "The University and Small Business Patent Procedures Act."

UAW. 1983. Solidarity: Blueprint for a Working America. May 16-31, Detroit, Michigan. 
Veysey, L. R. 1965. The Emergence of the American University. Chicago: The University of Chicago Press.

Zachary, G. Pascal. 1997. Endless Frontier: Vannevar Bush, Engineer of the American Century. New York: Free Press.

Ziman, John M. 1984. An Introduction to Science Studies: the Philosophical and Social Aspects of Science and Technology. Cambridge: Cambridge University Press. 